\section{The Chemical Exploration of the Stratosphere}

For his Friday evening discourse at the Royal Institution on November 6, Prof. F. A. Paneth took as his subject "The Chemical Exploration of the Stratosphere". Prof. Paneth pointed out that while the temperature and the electrical state of the stratosphere have been the object of many investigations, its chemical composition has seldom been studied. If winds are absent, or at least rare in the stratosphere, we should expect a partial separation of the atmospheric gases under the gravitational field of the earth. In order to decide this question of the stillness of the stratosphere, samples of air have to be collected. For this purpose, the sending up of automatic devices in unmanned balloons is the most efficient method. In collaboration with the Meteorological Office of the Air Ministry, Prof. Paneth and Dr. E. Glückauf, working at the Imperial College of Science and Technology, have developed methods for the automatic collection and subsequent analysis of air samples from the stratosphere. From the first results, published a year ago, it was concluded that up to $18 \mathrm{~km}$. no definite change in the chemical composition of the stratosphere occurred, but that at a height of $21 \mathrm{~km}$. the relative amount of the light gas helium has already distinctly increased. During the last few months, this has been confirmed by further successful flights reaching more than $23 \mathrm{~km}$.

SImILAR investigations have lately been started by Prof. E. Regener, in Stuttgart, using larger balloons; in one of his samples, from a height of more than $28 \mathrm{~km}$., he found an oxygen deficit, in good agreement with the helium surplus detected in the London flights. The only two air samples obtained by manned stratosphere balloons confirm these findings : Prokofiev's sample collected over Russia in 1933 at a height of $19 \mathrm{~km}$. showed no variation in its composition; but the air brought back by Capt. Stevens and Capt. Anderson from $22 \mathrm{~km}$. over the United States already revealed a slight oxygen deficit. All this supports the conclusion that from about $20 \mathrm{~km}$. onwards the stratosphere is quiet enough to permit a partial separation of its constituents by gravity. Neither the London nor the Stuttgart samples show a gradual change in the composition of the atmosphere in proportion to altitude. This is of special interest as it proves that in spite of their relative quietude, the air masses even of higher layers of the stratosphere are liable to disturbances, probably corresponding to weather conditions.

\section{The Royal Society of Arts}

For his inaugural address delivered on November 4 to the Royal Society of Arts, Sir Henry McMahon, chairman of the Society, took as his subject "One Hundred and Eighty Years of Pioneer Work by the Royal Society of Arts". The Society was founded in 1754 "for the Encouragement of Arts, Manufactures and Commerce" at a time when there were no departments of Government, societies or institutions to deal with such matters as Colonies, agriculture, forestry, fine arts, health, trade or industry.
In the early days, the field of work was divided into six sections, each being left to the charge of a separate committee. Money prizes, or premiums as they were called, and in some cases gold and silver medals, were then offered for specific objects, and in this way a very great stimulus was provided for improvements in all directions. The agricultural industry in particular derived much benefit from such a policy. At the time of the foundation of the Society, agricultural methods were largely based on medieval practice. In the second half of the eighteenth century, the Society took an important share in developing a more scientific outlook. The prizes offered by the Committee on agriculture covered a very wide range, including the improvement in the quality and yield of established crops, such as wheat, barley, oats and rye, the introduction of new grasses and roots for cattle feeding, better methods of cultivation, the invention of new types of agricultural machinery and the improvement of existing models, the use of manures, soil analysis, the management of sheep and eattle, and indeed almost every aspect of what is now understood by the term 'scientific agriculture'.

ThE offer of rewards did not always produce results. For example, a handsome reward was offered and renewed for no less than forty-six years (1774-1820) for an effective corn-reaping machine, without success. One of the most useful pieces of work for which the Society can claim credit was the introduction of the swede and mangel-wurzel into Great Britain. Remarkable results were also achieved by the Society in connexion with afforestation carried out in the period 1758-1835, anticipating in fact the work of the present Forestry Commission, which was not founded until 1919. Much attention has also been paid by the Society to the polite arts, the importance of encouraging the art of drawing in many employ. ments, trades and manufactures being recognized from the start. The introduction of industrial exhibitions was a feature of the pioneer work in this direction, and the success of the Exhibition of British Art in Industry in 1935 was an indication of the desire on the part of both designers and manufacturers of the present time to increase this spirit of co-operation.

\section{Prevention of War}

THERE can be no doubt of the general and passion. ate determination of the great majority of the thinking youth of the world to prevent another world war. This desire is strongly expressed by the New History Society, of 132 East 65th Street, New York, and illustrated by its offer of prizes amounting in the whole to five thousand dollars for the best papers submitted on the subject of "How Can the People of the World achieve Universal Disarmament?" The essays are to be of not more than two thousand words in length, and the prizes are variously graded from one thousand dollars downwards, so that there seems abundant opportunity for any helpful contribution sent in from any part of the world to receive some recognition. We recommend all 
sympathizers to obtain the necessary further particulars from the address above. The last date for the posting of the essays is May 1, 1937, so that ample time is allowed for all inquiries and for the writing of so short a composition. It will not be the length, however, but the pregnancy of what is said that will arouse attention, and one hopes most sincerely that something may be said which will bring light and hope to this most perplexing and dangerous question. Everyone knows, and most people admit, for example, that Great Britain in this matter of rearmament is acting most unwillingly and feels herself compelled to her present action by what is being done by others. If this is to go on, the vicious circle is complete. How to break it? That is the question to which the essayists will have to address themselves.

IT is not for us here to sketch an essay for the competition, but it does seem possibie that after our darkest moment light may appear. The appalling business which now absorbs our attention in Spain may prove the turning point for an upward move. ment of peace. It is clearly seen that this conflict is a reflection, in a distorted form, of the greatest underlying conflict which is threatening the peace all over the world, that between what is called 'fascism' or an authoritarian and comprehensive nationality, and 'communism' or the organized power of the manual workers. Men see now the hideous excesses and dangers of extinction which threaten civilization, if such a conflict is pushed to extremes. They must see also that, as in England, there is no essential reason why the conflict should not be avoided by rational compromise and good. will. There is an honest and widespread movement on foot to avoid extreme courses in the case of Spain. Clearly something must be done there, to save that country from extinction. This may be the lesson which the worId so badly needs. It is at least plainly written in the events of the last three months. The friends of science will also reflect that the crisis has occurred in the one land in Western Europe where science had taken least root, the one place where there was no renascence of science in the seventeenth century. That was the proper scene for the play of the forces of unreason. No other Western land has been torn by such an internecine strife; no other was so unfortunately free from the pacifying influences of scientific education.

\section{Spawning of the Common Toad}

IT is only during recent years that biologists have realized that they are far from a complete understanding of the influence of external factors on the spawning of even the commoner amphibians. The common toad (Bufo bufo bufo) is an 'explosive breeder', that is to say, all the sexually mature individuais in a district migrate from their diverse hibernation quarters to their breeding sites within a few days of one another, and within even large areas there is singularly little deviation from the normal of the year. There have been occasional records of isolated pairs found spawning long after the normal time, but sorne observations made by Mr. G. Shrub. sole, who writes from the Victoria Court Hotel, Eastbourne, made during the last two years, seem to indicate the existence in Sussex of an area which is exceptional. A series of small ponds on Beachy Head were visited at intervals for conchological work, and on July 30 and August 1, 1935, unhatched toad spawn was found in at least three of them. One pond was kept under observation and unmetamorphosed tadpoles were still found at the beginning of December. In 1936 tadpoles were first found in the same, and one other pond, at the beginning of May, but never throughout the year were they ever observed in any of the others. The development of the tadpoles was apparently very slow, for even in September the majority still had mere rudiments of hind-limbs. But whether these very late tadpoles were of the same brood as those found early in May is uncertain (the normal larval period is only 12-14 weeks), for although no fresh spawn was found, adult toads were discovered in the water in July. Their presence at a time so long after tadpoles had been observed is unusual, for the whole of the breeding operations are normally concluded within a week or so, and the adults then leave the water for the rest of the year. Their presence certainly suggests the possibility that there may have been a July spawning in 1936, as there was in 1935, and, if this proves to be a regular occurrence, a detailed investigation of the physical conditions of the district should be of importance.

\section{Native Labour from Nyasaland}

Tre announcement by the Colonial Office that the Governments of Southern Rhodesia, Northern Rhodesia and Nyasaland have entered into a provisional agreement regulating the employment of emigrant labour from the last-named has come shortly after Mr. Ormsby-Core's recent insistence on the importance of the labour problem in its effect on the well-being of the native community (see Narure, Oct. 31, p. 735). It is an assurance that the conditions to which the report of the Committee on emigrant labour from Nyasaland has directed attention will not be allowed to continue without a serious en. deavour to eliminate those factors which have been shown to be the cause of hardship and suffering, as well as a danger to the future prosperity of the Protectorate. The agreement is to remain in force for four years as from August 21 last, and thereafter is terminable at twelve months notice. Under its terms, identification certificates are to be issued to all male natives seeking employment, and those leaving their own territories for that purpose will bear evidence to that effect, as well as a notification of physical fitness. In future, so far as native and industrial conditions permit, only such certificated labour will be admitted by the employing Governments. Not only will the flow of labour be controlled, if necessary, but also-a matter of much greater importance-labourers are to be returned to their own territory after an economic period of employ. ment, which is not to exceed two years. This 